\title{
ANALISIS JUMLAH KANBAN PADA PROSES PRODUKSI SUPPORT ASSY BRAKE PEDAL PART NO. $X X X X-X X X X$ DI DEPARTEMEN WELDING PT. NTC (STUDI KASUS PERUSAHAAN SPARE PART AUTOMOTIVE)
}

\author{
Henri Ponda ${ }^{1)}$, Ramdhan Rusmanto ${ }^{2)}$ \\ ${ }^{1)}$ Staff Pengajar Program Studi Teknik Industri Universitas Muhammadiyah Tangerang \\ E-mail: henri_ponda@yahoo.com \\ ${ }^{2)}$ Praktisi Industri \\ E-mail:ramdhan_rusmanto@yahoo.com
}

\begin{abstract}
ABSTRAK
Pada saat ini teknologi yang digunakan pada sektor industri terus mengalami perubahan perbaikan dan berkembang dengan cepat. Dengan kemajuan teknologi yang sangat cepat industri-industri di Indonesia menerapkan manajemen produksi yang memegang peranan yang cukup penting adalah sistem produksi, karena sistem produksi merupakan rangkaian gabungan beberapa elemen yang saling menunjang dan berhubungan antara satu dengan yang lain untuk melaksanakan proses produksi dalam suatu perusahaan sehingga lebih efektif dan efisien. Prinsip JIT adalah menghilangkan pemborosan (eliminating waste) dan meningkatkan nilai tambah, yang akhirnya meningkatkan laba dan memperbaiki ROI (return on investment). ROI adalah laba dibagi dengan total asset. Sementara itu Laba adalah pendapatan dikurangi biaya. Jika biaya turun, maka laba naik dan akibatnya ROI naik. Kanban adalah suatu kartu mirip label yang berisi catatan-catatan tentang jumlah dan jenis unit yang diperlukan dan biasanya ditaruh dalam amplop vinil berbentuk empat persegi panjang atau bujur sangkar, yang dikirim pekerja dari suatu proses kepada pekerja pada proses yang terdahulu. Akibatnya, banyak proses dalam pabrik akan saling berkaitan. Jumlah Kanban yang dibutuhkan untuk membantu proses produksi Support Assy Brake Pedal Part No. $x x x x-x x x x$ di Departemen Welding yaitu berjumlah 1 (satu) Kanban.
\end{abstract}

Kata Kunci: Just In Time, Kanban, Waktu Siklus, Waktu Normal, Waktu Baku

\section{PENDAHULUAN}

Pada era globalisasi ini, industri merupakan salah satu sektor yang mengalami kemajuan sangat pesat. Pada saat ini teknologi yang digunakan pada sektor industri terus mengalami perubahan perbaikan dan berkembang dengan cepat. Dengan kemajuan teknologi yang sangat cepat industri-industri di Indonesia menerapkan manajemen produksi yang memegang peranan yang cukup penting adalah sistem produksi, karena sistem produksi merupakan rangkaian ga- bungan beberapa elemen yang saling menunjang dan berhubungan antara satu dengan yang lain untuk melaksanakan proses produksi dalam suatu perusahaan. Banyak industri yang ada di Indonesia saat ini, tetapi peneliti lebih tertarik kepada industri otomotif, khususnya yang menghasilkan komponen-komponen atau part-part mobil. Penulis ingin melihat dari dekat bagaimana suatu proses produksi dan perakitan berjalan di industri otomotif khususnya pada PT. NTC. 
PT. NTC merupakan salah satu perusahan yang menerapkan sistem produksi adaptasi dari perusahaan sejenisnya di Jepang. Sistem produksi yang diterapkan yaitu Sistem Kanban yang merupakan alat untuk mencapai sistem produksi tepat waktu (Just In Time) yang diperkenalkan oleh perusahaan Toyota Motor Corp. Japan. Untuk memenuhi jumlah permintaan pasar akan produk yang dihasilkan dan untuk dapat mengendalikan produksi yang diperlukan pada waktu yang diperlukan dalam setiap proses dibutuhkan perencanaan yang baik dari manajemen produksi berupa penerapan Sistem Kanban. Oleh karena itu aktivitas produksi yang terus ditingkatkan kualitasnya dengan penerapan dan perbaikan dari sistem produksi yang ada harus terus dipahami dan dilaksanakan dengan baik oleh seluruh karyawan dan staff manajemen. Untuk itu dibutuhkan pengetahuan yang cukup mengenai sistem tarik (Sistem Kanban) ini.

\section{PERUMUSAN MASALAH}

Peneliti mencoba menganalisa Sistem Kanban yang berlaku di PT. NTC dengan memfokuskan pada kebutuhan jumlah Kanban. Adapun yang menjadi pokok pemasalahan yaitu, menentukan berapa jumlah Kanban teoritis pada proses perakitan Support Assy Brake Pedal part no. xxxx-xxxx pada departemen welding. Alasan memilih part tersebut dalam perhitungan Kanban karena part tersebut sering diproduksi atau diorder oleh PT. TMMI.

\section{TUJUAN PENELITIAN}

Tujuan dari penelitian ini adalah untuk mengetahui jumlah kanban yang dibutuhkan dalam proses perakitan komponen Support Assy Brake Pedal part no. xxxx-xxxx pada departemen welding. Serta menjadi referensi untuk penelitian-penelitian berikutnya, sehingga dapat mengembangkan teknik kanban.

\section{METODOLOGI PENELITIAN}

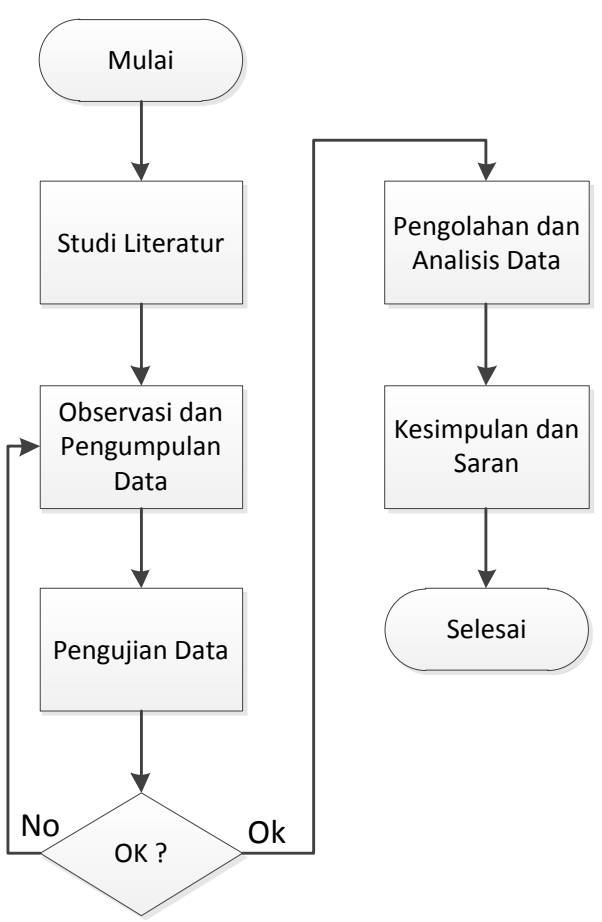

Gambar 1. Alur Metodologi Penelitian

\section{LANDASAN TEORI}

\subsection{Pengertian JIT (Just In Time)}

Just In Time adalah suatu pendekatan yang berusaha menghilangkan semua pemborosan, sesuatu yang tidak menambah nilai, di dalam kegiatan produksi dengan memproduksi berdasarkan atas jumlah barang yang benar-benar diperlukan secara tepat waktu pada saat dibutuhkan. Konsep JIT muncul di Jepang melalui apa yang disebut Kaizen (perbaikan terus menerus). Just In Time (JIT) sendiri bukan istilah Jepang tetapi istilah dari Barat yang mampu melihat fenomena manajemen di Jepang.

Prinsip JIT adalah menghilangkan pemborosan (eliminating waste) dan meningkatkan nilai tambah, yang akhirnya meningkatkan laba dan memperbaiki ROI (return on investment). ROI adalah laba dibagi dengan total asset. Sementara itu Laba adalah pendapatan dikurangi biaya. Jika biaya turun, maka laba naik dan akibatnya ROI naik. 
Sistem JIT dikembangkan pada Toyota Motor Company di Jepang. Meskipun Schonberger (1982) mengindikasikan bahwa JIT mungkin sudah ada 20 tahun lalu pada industri galangan kapal Jepang, namun penerapan JIT modern dipopulerkan pada pertengahan dekade 1970-an pada Toyota oleh Mr. Taiichi Ohno, seorang wakil direktur utama, serta beberapa teman sejawatnya. Konsep JIT kemudian secara nyata ditransfer pertama kali ke Amerika Serikat sekitar tahun 1980 pada Kawasaki's Lincoln, pabrik Nebraska.

Ciri-ciri khas dari JIT adalah: arus barang berdasarkan pull method, kualitas produksi setiap tahap selalu diusahakan baik, ukuran order selalu sedikit, waktu setup pendek, beban kerja yang seimbang, menggunakan komponen dan metode standar, ada hubungan dekat dengan konsumen, sumberdaya manusia yang fleksibel, produksi berfokus pada produk, digunakan automatisasi, dan pemeliharaan dilaksanakan dengan sangat baik.

\subsection{Continuous Improvement Dalam Just In Time}

Dalam JIT biasanya dilengkapi dengan Continous Improvement atau perbaikan yang terus-menerus. Perbaikan ini berupa penemuan sesuatu yang baru untuk memperbaiki yang sudah ada, mencari kelemahan atau penyebab masalah, serta berbagai usaha preventif yang perlu dilakukan. Perbedaan dengan cara yang klasik adalah dalam JIT selalu diusahakan pemecahan masalah yang timbul sekaligus dengan mencari penyebab masalah itu, sehingga setiap persoalan yang timbul selalu diatasi secara tuntas. Pekerjaan ini tidak akan selesai, karena tugas yang dilakukan dalam Continous Improvement adalah selalu mencari masalah yang masih perlu diatasi. Dan ini tidak akan selesai. Kalau dalam cara klasik, masalah diatasi seperlunya aja. Misalnya masalah kekurangan bahan diatasi dengan menyediakan cadangan atau persediaan. Sedang dalam JIT disamping kekurangan itu ditutup, juga dicari penyebabnya yang harus diatasi sehingga dilain waktu tidak akan menimbulkan masalah lagi. Jumlah persediaan barang kalau selalu diadakan studi akan diketahui dengan lebih tepat kebutuhannya.

\subsection{Sistem Kanban}

Sistem Kanban adalah suatu sistem informasi yang secara serasi mengendalikan produksi produk yang diperlukan dalam jumlah yang diperlukan pada waktu diperlukan dalam setiap lantai produksi pada pabrik dan juga diantara perusahaan. Sistem Kanban juga suatu alat untuk mencapai JIT.

Kanban adalah suatu kartu mirip label yang berisi catatan-catatan tentang jumlah dan jenis unit yang diperlukan dan biasanya ditaruh dalam amplop vinil berbentuk empat persegi panjang atau bujur sangkar, yang dikirim pekerja dari suatu proses kepada pekerja pada proses yang terdahulu. Akibatnya, banyak proses dalam pabrik akan saling berkaitan.

Kait-mengaitnya berbagai proses dalam pabrik ini memungkinkan pengendalian yang lebih baik dalam jumlah hal yang diperlukan untuk berbagai produk. Dalam JIT ada yang menggunakan satu kartu, ada pula yang menggunakan dua kartu. Kebanyakan pabrik sekarang menggunakan dua kartu karena lebih mudah dilaksanakan, meskipun kenyataannya akan menyebabkan sistem ini tidak murni zero level inventory, karena ada satu cadangan container barang yang siap dikirimkan. Toyota menggunakan dua kartu. 


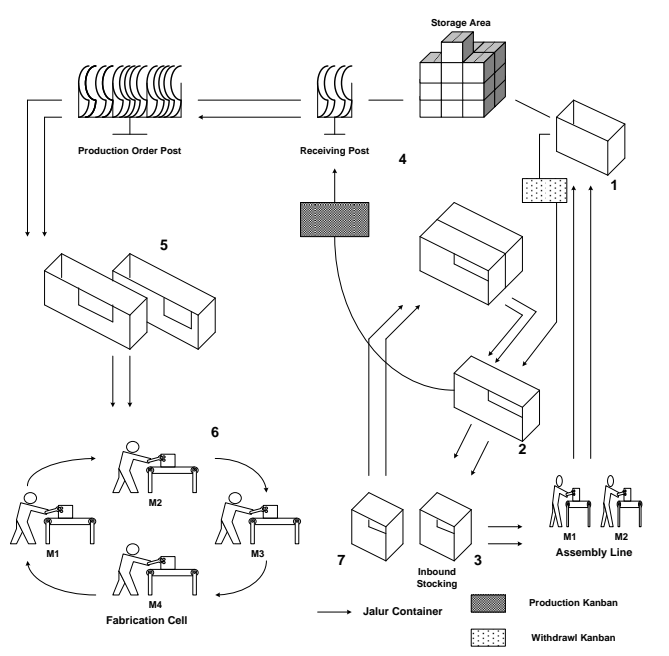

Gambar 2. Sistem Kanban dengan Dua Kartu

Sistem Kanban didukung oleh hal-hal berikut:

1. Pelancaran produksi,

2. Pembakuan pekerjaan,

3. Pengurangan waktu penyiapan,

4. Aktivitas Perbaikan,

5. Rancangan tata ruang mesin, dan

6. Autonomasi (Sistem Pengendali Cacat Secara Otonom).

\subsection{Jenis-jenis Kanban}

Jenis-jenis Kanban yang sering digunakan, yaitu:

1. Kanban Pengambil (Withdrawl Kanban) Suatu Kanban Pengambil menspesifikasikan jenis dan jumlah produk yang harus diambil dari proses terdahulu dari proses berikutnya.

2. Kanban Perintah Produksi (Production Kanban)

Kanban perintah produksi menspesifikasikan jenis dan jumlah produk yang harus dihasilkan proses terdahulu. Kanban perintah produksi sering disebut Kanban dalam pengolahan atau secara sederhana, Kanban Produksi.

3. Kanban Pemasok (Supplier Kanban)

Kanban Pemasok digunakan untuk melaksanakan pengambilan dari jumlah (Pemasok suku cadang atau bahan, juga disebut subkontraktor). Kanban pemasok berisi perintah yang meminta pemasok atau subkontraktor untuk mengirimkan suku cadang.

4. Kanban Pemberi Tanda (Signal Kanban) Kanban pemberi tanda digunakan untuk menerangkan spesifikasi produksi lot dalam setiap proses terdahulu maupun sebelumnya. Kanban pemberi tanda ditempelkan pada suatu kotak dalam lot. Kalau pengambilan mencapai kotak yang ditempeli Kanban ini instruksi produksi harus digerakkan. Dari dua jenis Kanban pemberi tanda ini, yang pertama adalah Kanban Segitiga yang terbuat dari lembaran logam dan cukup berat. Jenis Kanban kedua yaitu Kanban berbentuk segi empat dan disebut Kanban Peminta Bahan.

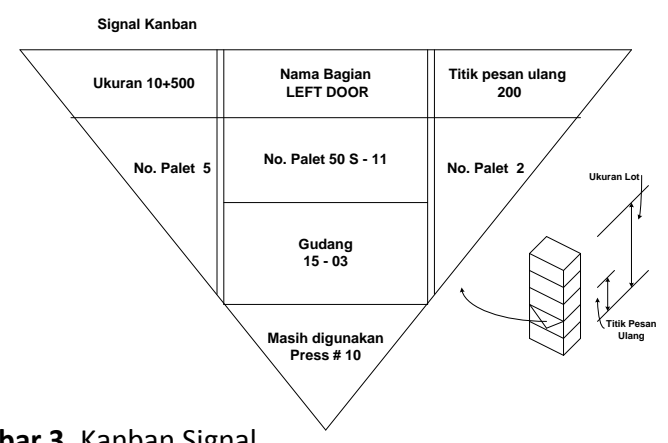

Gambar 3. Kanban Signal

\subsection{Fungsi Sistem Kanban}

Untuk menerapkan konsep Kanban secara efektif, kita perlu memahami fungsinya secara jelas dan mendalam. Fungsi sistem Kanban adalah:

1. Meniadakan Muda, akibat memproduksi secara berlebihan

- Hanya memproduksi sebanyak yang akan diambil dan yang akan digunakan oleh proses berikutnya.

- Memproduksi barang pada saat tidak diperlukan, melebihi jumlah yang diperlukan dan menambah stock, hanya akan menimbulkan bermacammacam kerugian. 
2. Informasi pengambilan dan informasi perintah produksi

- Dengan menggunakan Kanban, informasi mengenai part apa, kapan, berapa banyak diproduksi dan bagaimana pengangkutannya akan mengalir secara jelas sebagai perintah produksi.

3. Alat untuk mengontrol secara visual (Kanban bergerak bersama barang)

- Prinsip pengontrolan visual adalah dapat dilakukan judgement dengan cepat pada saat normal dan abnormal, pada benda dan tempat dll, karena Kanban bergerak bersama barang, maka Kanban mempunyai fungsi yang penting sebagai alat control visual.

4. Alat untuk improvement

- Jika Kanban fluktuasi, dapat dicari penyebab utamanya, kemudian dibuatkan countermeasure improvement-nya.

- Jika jumlah Kanban terlalu banyak, stock akan meningkat, oleh karena itu jumlah Kanban harus dikurangi.

\subsection{Perhitungan Jumlah Kanban}

Persamaan yang dapat digunakan untuk menghitung jumlah Kanban adalah sebagai berikut:

$k=$ rata - rata permintaan sepanjang lead time dan safety stock

$k=\frac{d(\bar{w}+\bar{p})(1+\alpha)}{c}$

keterangan:

k : jumlah production kanban/withdrawl kanban untuk suatu part.

d : rata-rata permintaan harian untuk part (dalam unit).

w : rata-rata waktu tunggu sepanjang proses produksi ditambah waktu penanganan bahan per kontainer (dalam fraksi satu hari).

p : rata-rata waktu bahan per kontainer (dalam fraksi satu hari).

c : kuantitas container standar untuk part. $\alpha$ : suatu variabel kebijaksanaan yang merefleksikan efisiensi stasiun kerja memproduksi atau menggunakan part (Toyota menggunakan $\leq 10 \%$ ).

\subsection{Pengujian Data}

Pengukuran waktu ini menggunakan jam henti (stopwatch) sebagai alat utamanya. Cara ini merupakan cara yang paling banyak dikenal, dan karenanya banyak digunakan. Salah satu yang menyebabkan adalah keserderhanaan aturan-aturan ajaran yang dipakai (Iftikar Z. Sutalaksana). Pengaturan waktu ini dalam pengambilan data waktu langsung disebelah operator dan pengambilan datanya disesuaikan dengan kebutuhan.

$>$ Hitung rata-rata dari harga rata-rata sub grub dengan:

$$
\overline{\bar{X}}=\frac{\sum X i}{k}
$$

Dimana:

$x=$ harga rata-rata dari sub grup ke-1.

$\mathrm{k}$ = harga banyaknya sub grup yang terbentuk.

Hitung standard deviasi sebenarnya dari waktu penyelesaian dengan:

$$
\sigma=\sqrt{\frac{\sum\left(X_{j}-\overline{\bar{x}}\right)^{2}}{n-1}}
$$

Dimana:

$n$ = jumlah pengamatan pendahuluan yang telah dilakukan.

$X=$ waktu penyelesaian yang teramati selama pengukuran pendahuluan yang telah dilakukan.

Hitung standar deviasi dari distribusi harga rata-rata sub grup dengan:

$$
\sigma \bar{x}=\frac{\sigma}{\sqrt{n}}
$$

Dimana: $\mathrm{n}=$ besarnya sub grup.

Tentukan Batas Kontrol Atas dan Batas Kontrol Bawah (BKA dan BKB) dengan:

$$
B K A=\bar{X}+3 \sigma \bar{x}
$$


Menghitung banyaknya pengukuran yang diperlukan dengan:

$$
N^{\prime}=\left[\frac{40 \sqrt{N \sum x_{i}^{2}-\left(\sum x_{i}\right)^{2}}}{\sum x_{i}}\right]^{2}
$$

dimana:

$$
\begin{aligned}
& \mathrm{N}=\text { jumlah pengamatan yang telah } \\
& \text { dilakukan. }
\end{aligned}
$$

\subsection{Perhitungan Waktu Baku}

Hitung waktu siklus rata-rata dengan:

$$
W s=\frac{\sum X_{i}}{N}
$$

Dimana $\mathrm{X}_{\mathrm{i}}$ dan $\mathrm{N}$ menunjukkan arti yang sama dengan yang telah dibahas selanjutnya.

Hitung waktu normal dengan:

$$
W n=W s * p
$$

Dimana $\mathrm{p}$ adalah faktor penyesuaian. Faktor ini diperhitungkan jika pengukur berpendapat bahwa operator bekerja dengan kecepatan tidak wajar, sehingga hasil perhitungan waktu perlu disesuaikan atau dinormalkan dulu untuk mendapat waktu silkus rata-rata yang wajar. Jika pekerja bekerja dengan wajar, maka faktor penyesuaiannya $\mathrm{p}$ sama dengan 1 , artinya waktu siklus rata-rata sudah normal. Jika bekerjanya terlalu lambat maka untuk menormalkannya pengukur harus memberi harga $p<1$, dan sebaliknya $p>1$ jika dianggap bekerja cepat.

Hitung waktu baku dengan:

$$
W b=W n+(W n * \text { Allowance })
$$

Allowance diberikan diberikan kepada pekerja untuk mengerjakan pekerjaannya disamping waktu normal. Kelonggaran ini diberikan untuk hal-hal seperti kebutuhan pribadi, menghilangkan rasa fatique dan gangguan-gangguan yang mungkin terjadi yang tidak dapat dihin-

\begin{tabular}{|c|c|c|}
\hline \multirow{2}{*}{$\begin{array}{l}\text { Waktu } \\
\text { SIklus }\end{array}$} & \multicolumn{2}{|c|}{ Sub Grup } \\
\hline & 1 & 2 \\
\hline 1 & 93,36 & 93,56 \\
\hline 2 & 94,27 & 93,16 \\
\hline 3 & 93,21 & 92,34 \\
\hline 4 & 92,46 & 92,45 \\
\hline 5 & 93,29 & 93,43 \\
\hline 6 & 93,46 & 93,07 \\
\hline 7 & 92,31 & 93,24 \\
\hline 8 & 93,11 & 94,21 \\
\hline 9 & 94,54 & 93,31 \\
\hline 10 & 92,02 & 93,26 \\
\hline$\Sigma$ & 932,03 & 932,03 \\
\hline Rata2 & 93,2 & 93,2 \\
\hline
\end{tabular}
darkan oleh pekerja. Umumnya kelong- garan dinyatakan dalam persendari waktu normal.

\section{Analisis dan Pengolahan Data}

6.1. Uji Keseragaman Data

Diketahui:

$$
\begin{aligned}
& \bar{x}_{1}=93,2 \quad \bar{x}_{2}=93.2 \\
& \mathrm{~m}=2 \Rightarrow \text { jumlah sub group } \\
& \begin{aligned}
& \bar{x}=\frac{\sum \bar{x}}{m}=\frac{93,2+93,2}{2}=93,2 \\
& \sigma=\sqrt{\frac{\sum\left(x_{j}-\overline{\bar{x}}\right)^{2}}{n-1}} \\
&=\sqrt{\frac{(93,36-93,2)^{2}+(94,27-93,2)^{2}+\ldots .+(93,31-93,2)^{2}+(93,26-93,2)^{2}}{20-1}} \\
&= \sqrt{\frac{8,3226}{19}}=\sqrt{0,438}=0,6618 \\
& \sigma \bar{x}=\frac{\sigma}{\sqrt{n}}=\frac{0.6618}{\sqrt{2}}=0.468 \\
& \text { BKA }=\bar{x}+3(\sigma \bar{x})=93,2+3(0.468)=93,2+1,404=94,604 \\
& \text { BKB }=\bar{x}-3(\sigma \bar{x})=93,2-3(0,468)=93,2-1,404=91,796
\end{aligned}
\end{aligned}
$$

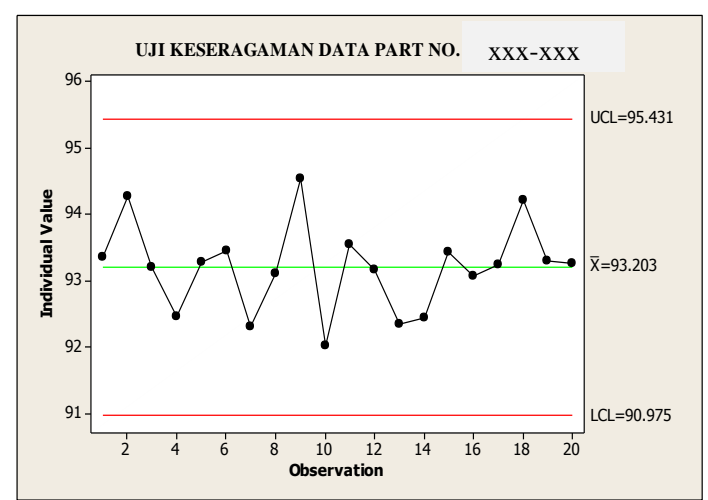

Gambar 4. Grafik Uji Keseragaman Data 


\subsection{Uji Kecukupan Data}

Uji kecukupan data dilakukan untuk mengetahui apakah data waktu siklus yang diambil sudah cukup apa belum. Jumlah pengukuran data dikatakan cukup apabila jumlah pengukuran yang dilakukan telah memenuhi jumlah pengukuran yang diper-lukan $\left(\mathrm{N}^{\prime}<\mathrm{N}\right)$.

$$
\begin{aligned}
& N^{\prime}=\left[\frac{40 \sqrt{N \sum x_{i}^{2}-\left(\sum x_{i}\right)^{2}}}{\sum x_{i}}\right]^{2} \\
& N^{\prime}=\left(\frac{40 \sqrt{20 * 173744,3066-(3474719,684)}}{1864,06}\right)^{2} \\
& N^{\prime}=\left(\frac{516,06}{1864,06}\right)^{2} \\
& N^{\prime}=(0,277)^{2} \rightarrow N^{\prime}=0,077
\end{aligned}
$$

\subsection{Faktor Kelonggaran}

Faktor kelonggaran diberikan untuk 3 hal berikut yaitu kebutuhan pribadi, menghilangkan rasa fatique, dan hambatan-hambatan yang tidak dapat dihindarkan.

1. Tenaga yang dikeluarkan Sangat ringan (bekerja dimesin, berdiri)

2. Sikap kerja Berdiri diatas 2 kaki

Gerakan kerja Normal (ayunan bebas)

4. Kelelahan mata Pandangan yang hampir terus menerus $\quad 6 \%$

5. Keadaan temperatur tempat kerja Normal $\left(22^{\circ}-28^{\circ}\right)$

6. Keadaan Atmosfir Baik (ruang yang berventilasi baik, udara segar)

7. Keadaan lingkungan yang baik Sangat bising

Jadi presentase kelonggaran untuk kebutuhan pribadi dan untuk fatique sebagai berikut:

$\Rightarrow 6 \%+1 \%+0 \%+6 \%+0 \%+0 \%+3 \%=16 \%$.

Kelonggaran untuk hambatan yang tidak terhindarkan (efisiensi) adalah 20\% (ditetapkan oleh pabrik), maka kelonggaran total yang harus diberikan adalah $16 \%+20 \%$ $=36 \%$

\subsection{Perhitungan Waktu Baku}

$$
\begin{aligned}
W s & =\frac{\sum X_{i}}{N} \\
& =\frac{1864}{20}=93,2 \\
W n & =W s \times P \\
& =93,2 \times 1,25 \\
& =116,5 \\
W b & =W n+(\text { Wn } * \text { Allowance }) \\
& =116,5+(116,5 * 0.36) \\
& =158,44
\end{aligned}
$$

\subsection{Perhitungan Jumlah Kanban}

- Rata-rata permintaan harian =

Permintaan dalam satu bulan Jumlah hari kerja $=\frac{6074}{23}=265$ unit

- kuantitas container $=10$ unit

- $\quad$ waktu siklus dalam periode 1 hari =

$$
\frac{\text { Waktu siklus per part }}{\text { Jumlah jam keja }}
$$

$$
=\frac{158,44}{60 * 60 * 16}=0,00275 \text { hari }
$$

- $(\bar{w}+\bar{p})=$ waktu siklus dalam periode 1 hari ${ }^{*} c=0,00275 * 10=0,0275$ hari

- Berdasarkan perhitungan-perhitungan di atas maka di dapatkan jumlah kartu Kanban sebagai berikut:

$$
\begin{aligned}
& k=\frac{d(\bar{w}+\bar{p})(1+\alpha)}{c} \\
& k=\frac{265(0,0275)(1+0)}{10} \\
& k=0,729 \approx 1 \text { kartu }
\end{aligned}
$$




\section{KESIMPULAN DAN SARAN}

\subsection{Kesimpulan}

Berdasarkan pengolahan data dan analisa data-data yang penulis dapatkan selama menyusun Laporan Kerja Praktek ini didapatkan kesimpulan sebagai berikut:

1. Pengujian keseragaman data yang telah dilakukan menyatakan bahwa data yang dikumpulkan berasal dari populasi yang sama (seragam). Hal ini dikarenakan data berada direntang BKA dan BKB.

2. Hasil pengujian kecukupan data menunjukkan bawah $\mathrm{N}^{\prime}<\mathrm{N}$. Hal ini dapat dinyatakan bahwa data yang dikumpulkan sudah mencukupi untuk dilakukan pengolaha data selanjutnya.

3. Jumlah Kanban yang dibutuhkan pada Proses Produksi Support Assy Brake Pedal Part No. $x x x x-x x x x d i$ Departemen Welding PT. NTC berjumlah 1 (satu).

\subsection{Saran}

Agar Sistem Kanban dapat berjalan dengan baik, perlu dilakukan tindakan-tindakan sebagai berikut:

1. Memberikan pemahaman kepada semua operator/staff untuk melakukan perbaikan secara terus-menerus (kaizen).

2. Memberikan pemahaman kepada setiap operator agar menghasilkan part dengan kualitas yang baik karena salah satu tujuan dari sistem JIT adalah zero defect.

3. Mengurangi safety stock pada stasiun kerja secara berkala.

4. Melakukan standarisasi dan metode kerja untuk efisiensi kerja.

5. Melakukan analisa ketergantungan dan keseimbangan lintasan (line balancing) antar stasiun kerja dalam lintasan lantai produksi.

\section{DAFTAR PUSTAKA}

Gaspersz, Vincent. 1998. Production Planning And Inventory Control Berdasarkan Sistem Terintegrasi MRP II Dan JIT Menuju Manufacturing 21. Jakarta: Gramedia Pustaka Utama.

Monden, Yasuhiro. 1995. Sistem Produksi Toyota, Buku Pertama. PT. Pustaka Binaman Pressindo.

Monden, Yasuhiro. 1995. Sistem Produksi Toyota. Buku Kedua. PT. Pustaka Binaman Pressindo.

Schroeder, Roger G. 1997. Manajemen Operasi Pengambilan Keputusan dalam Suatu Fungsi Operasi. Jilid ke-2. Jakarta: Erlangga.

Subagyo, Pangestu, Manajemen Operasi, Yogyakarta, BPFE, 2000.

Sutalaksana, Iftikar Z. 1979. Teknik Tata Cara Kerja. Jurusan Teknik Industri: Institut Teknologi Bandung. 